
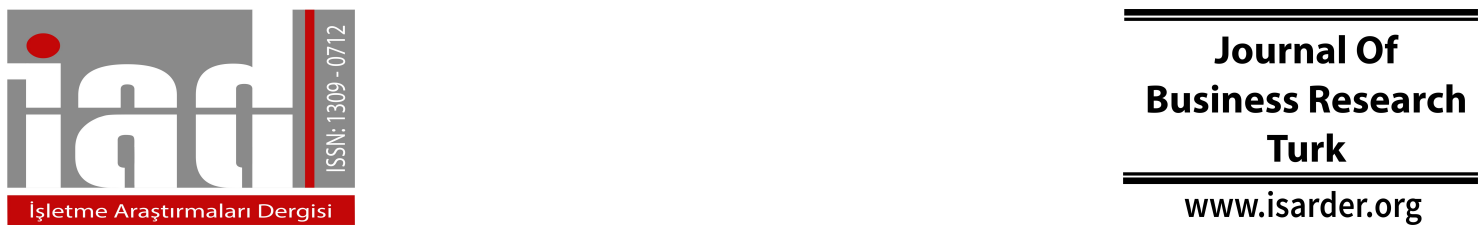

\title{
A Contemporary Approach For Strategic Management in Tourism Sector: PESTEL Analysis on The City Muğla, Turkey
}

\author{
Ergün KARA \\ Osmaniye Korkut Ata University \\ Faculty of Economics and Administration Sciences \\ Management Information Systems Department \\ Osmaniye, Turkey \\ orcid.org/0000-0002-7815-1111 \\ ergunkara@,osmaniye.edu.tr
}

\begin{abstract}
The scope of the present study is to estimate the influence of the PESTEL dimensions (political, economic, social, technological, environmental and legal) on the tourism sector in Muğla, Turkey. For this purpose, a research has been carried out on the top managers of three, four and five-star hotels operating in Muğla, Turkey. The datum provided from 150 business top managers have been included to the analysis of the research. As a result of the analysis done, legal factors (consumer and labor law) were estimated by the participant managers as the most important whereas social factors (demographic structure of the population and cultural attitudes) were of the least importance for the development of tourism sector in Muğla, Turkey. Another result was that more educated participants gave greater importance to all these factors than their less educated counterparts.
\end{abstract}

Keywords: PESTEL model, management, business administration strategy

\section{INTRODUCTION}

Strategic management is a proactive approach to business. It encompasses past experiences, present situation, and future-related anticipations of a constellation of various relevant factors that can affect business development or its decline. In other words, strategic planning, resource management, implementing selected strategies, and evaluating this process is of a crucial significance to an organization (Steiss 2003). Thus, it is important to be familiar with various strategic procedures that emerge from deep analysis of strengths and weaknesses of a particular business subject (internal environment), as well as opportunities and threats to it (external environment). Internal environment is analyzed by different methods, systems, and tools. Furthermore, various models were proposed to capture external environment, relevant to the economy of a firm (Yüksel 2012). 
One of the models of this kind is the so-called PESTEL (or PESTLE) analysis. It is widely accepted as a comprehensive method used for industry and market assessment (Kolinos \& Read 2013). It is the acronym for political, economic, social, technological, environmental, and legal factors (dimensions) that can influence organizational success and/or its failure. It is an approach to the estimation of the external business environment (Gupta 2013). Political factors are, for instance, tax regulations, government stability, and corruption levels (Team FME, 2013). Level of economic growth could be one of the key economic factors (Cadle, Paul, \& Turner 2010), and some other factors in this group are GDP, GNP, inflation, and exchange rates (Ritson 2008). Social factors include cultural, demographic and other social influences (Ho 2014). In other words, social factors are values, the culture, and residents (Song, Sun, \& Jin 2017). Technological factors are usually of two kinds. These are development in IT and improvements of technology related to industry and marketing (Cadle, Paul, \& Turner 2010). The results of technological improvement and upgrade are product innovations, applications of knowledge, and new communication technologies (Hitt, Ireland, \& Hoskisson 2007). Environmental influences include ecological issues, cyclical weather, disposal of materials, etc. (Team FME 2013). The major legal factors are consumer and competition laws, health and safety legislation, and employment laws (Gillespie 2016).

There are also models similar to PESTEL, which for example include some more factors. These are STEEPLE model (ethical factors), PESTLIED (international and demographic factors), and STEEPLED (educational and demographic factors). PESTEL model was also extended by adding three distinctive categories of factors to the mentioned six factors. They are local, national, and global and the new model is abbreviated as LONGPESTEL (Gillespie 2016). There also exists a simplified version of this analysis (PEST), that includes only four out of the six factors: political, economic, social, and technological (e.g. Sammut-Bonnici \& Galea 2015).

A vast majority of studies on the PESTEL's analytical framework were qualitative ones. For example, Andrei and Prisecaru (2014) conducted a PESTEL analysis on the geological repository in Romania. For example, they concluded that inflation and interest rate (as two economic factors) in their country had a significant impact on radioactive waste disposal costs. Some authors, for example, identified the subfactors within PESTEL model and classified them into the two groups - "threats" and "opportunities" for Indonesia maritime security (Putra et al. 2017). Another example was a qualitative analysis of factors influencing garments industry in Bangladesh (Islam \& Pattack 2017). The authors of this study highlighted that government supports garments industry (which refers to legal factors); however, most of the techonologies used in this industry sector are obsolete.

This model that explains future business dynamics can be applied to each industry sector (Johnson et al. 2011). Because the six factors mentioned before are macroeconomic influences or segments of the international environment, we can apply PESTEL analysis to the tourism sector of a country (Gregoric 2014). Some examples encompassed: macro-environmental influences on rural tourism in Lithuania (Barkauskas, Barkauskiene, \& Jasinskas 2015), perspectives of business tourism in Croatia and Qatar (Gregorić 2014), strategic issues and challenges of tourism in Kenya (Mayaka \& Prasad 2012), hospitality and tourism industry sustainability in India (Suri 
\& Kumar 2016), environmental strategic factor analysis of the tourism industry in Sri Lanka (Rauf 2014).

Accordingly, the main scope of this study was to investigate the importance of political, economic, social, technological, environmental, and legal factors to the tourism industry in Turkey. This study attempts to provide answers to the following research questions:

a) What is the importance of each factor proposed within PESTEL analysis to the tourism sector in Muğla?

b) Are there statistically significant differences in the degree of importance of each factor?

c) Are there statistically significant correlations of PESTEL factors with participants' age, working experience (overall and for the present company), and levels of education?

\section{METHODS}

\subsection{Participants}

The scope of this researchis formed by the top managers of hospitalitybusiness with the tourism management certifacate of 3, 4 and 5 stars 195 hotels being operatedin muğla. The sampling of the research is 150 hospitality management top directors on whom the questionnaires were developed as to counting the largeness os sampling in literatüre. The propositions found in the questionnaire study to be done have been prepared so that it couldtest the basic hypothesis bye the research team with questions and expressions (Ural and Kilic, 2006). Here, $\mathrm{N}$ indicates:tottal hospitality management numbers, $\mathrm{n}$ : indicates the number of managemenet to be included in the questionnaire, $\mathrm{p}$ : indicates the probability of the realisation of event studied, q: indicater probability of studied event's not being realised ( $q=1-p)$, $t$ : indicates the" $t$ " table value at a specific meaningfullness levedand $d$ indicates the sampling error accepted. In formula, $\mathrm{p}$ and $\mathrm{q}$ values have been taken as 0,5 . ' $T$ '" table value for the sampling meaningfulness level $(\alpha: 0,05)$ has been taken as 1,53 and the accepted sampling as (d) 0,03 (Ural and Kiliç,2006). The research has been conducted on is a top directors working in the aforementioned managements.

$$
n=\frac{\mathrm{N} * \mathrm{t}^{2} * \mathrm{p} * \mathrm{q}}{\mathrm{d}^{2} *(\mathrm{~N}-1)+\mathrm{t}^{2} * \mathrm{p} * \mathrm{q}} \quad n=\frac{195 * 1,53^{2} * 0,5 * 0,5}{0,03^{2} *(195-1)+1,53^{2} * 0,5 * 0,5}=150
$$

The hospitality management has been chosen, the directors working in them has been conducted the questionnaires and an evaluation was done according to the findings provided.

A total of 150 managers participated in this research. There were 84 males $(56 \%$ of the total sample) and 66 females (44\%). Participants' mean age was $M=43.04$ (with the standard deviation $S D=8.75)$. The youngest participant was 28 whereas the oldest one was 63 years old. 


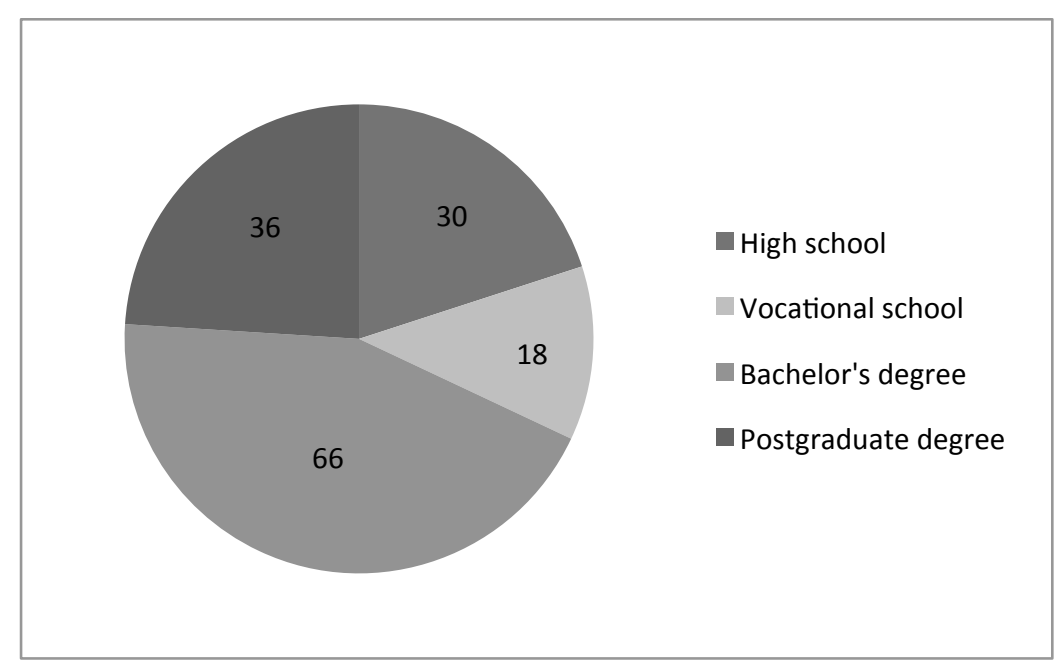

Figure 1. Sample Structure By Participants' Level Of Education

As seen in Figure 1, the largest number of participants hold some bachelor's degree $(N=66$, which is $44 \%$ of the sample). Thirty-six (24\%) participants hold a postgraduate degree, 30 participants $(20 \%$ of the whole sample) finished high school, and $18(12 \%)$ participants finished some vocational school.

The least reported number of years working with the present company was one whereas the greatest one was 20. On average, our sample of managers has been working for the present company for $M=6.08$ years $(S D=3.77)$. Based on the number of years spent working with the current company, we divided them into four groups $(1-5,6-$ 10, $11-15$, and $16-20$ years, see Figure 2).

As was displayed in Figure 2, the majority of our participants $(N=78$ or $52 \%$ of the total sample) have been working for their current company for $1-5$ years. The minority of our respondents $(\mathrm{N}=3$, which is $2 \%)$ have been working for $16-20$ years for their present company.

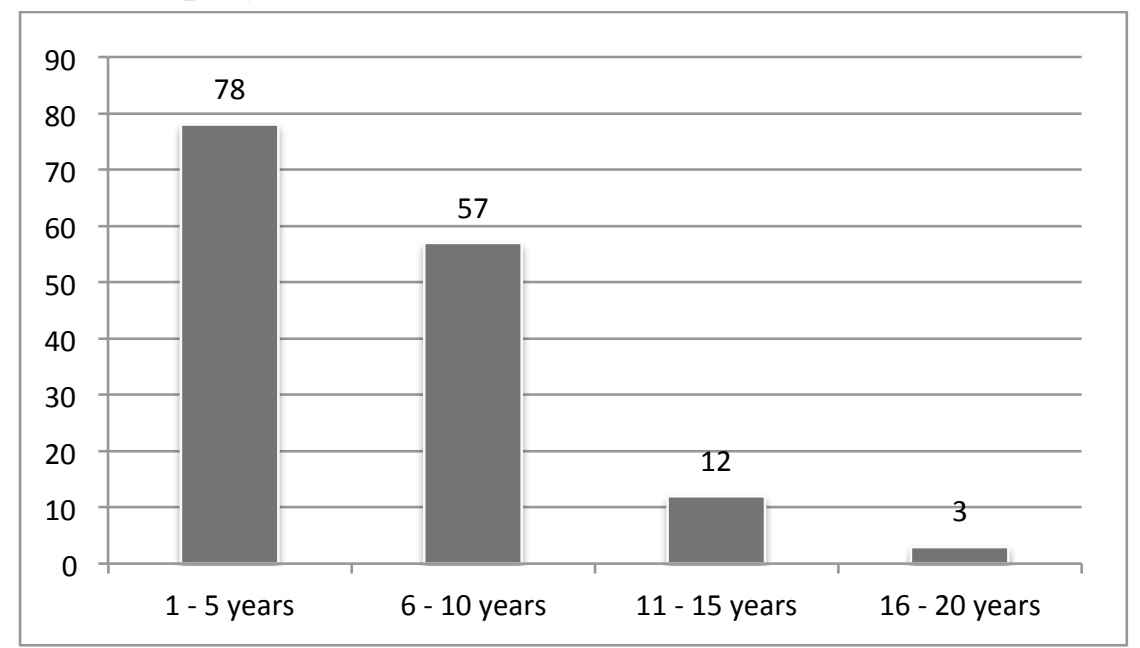

Figure 2. Participants Divided Into Groups By The Number Of Years They Have Been Working For The Present Company

Overall working experience of the participants ranged from three to 37 . The average value of working years was $M=17.92(S D=8.55)$. We divided the sample into four groups by their overall working experience $(1-10,11-20,21-30$, and $31-40$ years), in order to make Figure 3. 


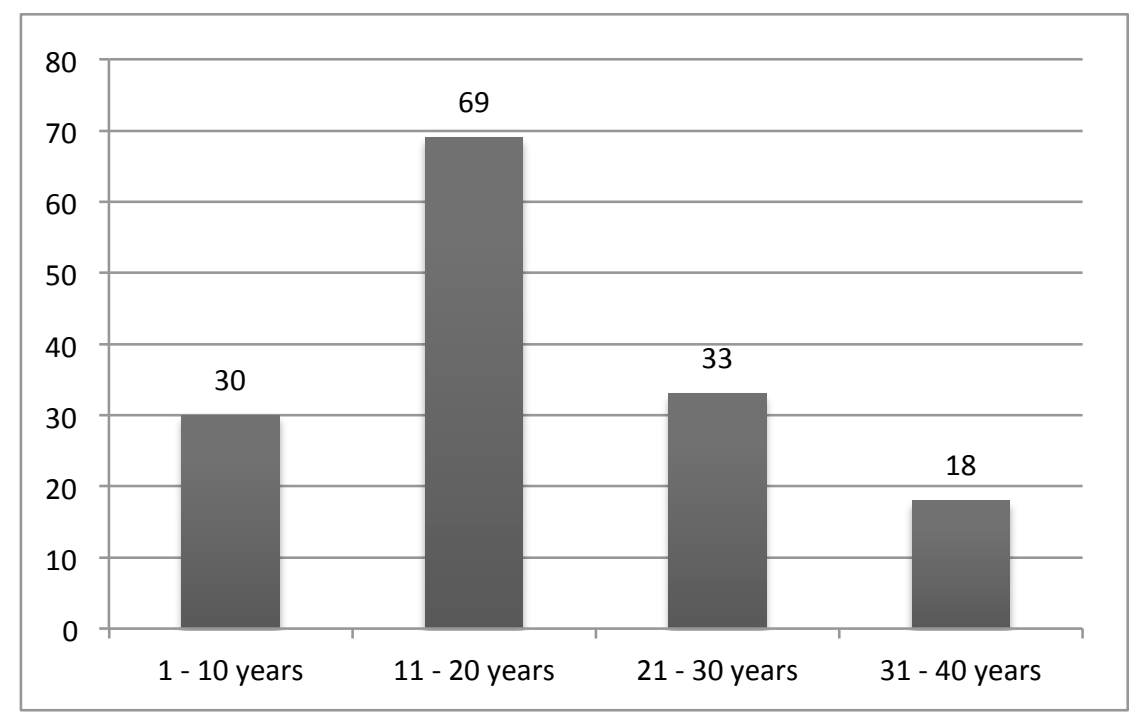

Figure 3. Number Of Participants In The Four Groups Formed By The Overall Working Experience

Most of our participants had $11-20$ years' working experience $(N=69$, i.e. $46 \%$ of the total sample, see Figure 3). The smallest portion of our sample had $31-40$ years of working experience ( $N=18$, or $12 \%$ of the total sample).

\subsection{Instruments}

The instrument used in this study had two parts. The first one included questions about some relevant sociodemographics (participants' gender, age, their level of education, a total number of years working for the present company and overall number of years since the first employment).

The second part included a 5-point rating scale of the Likert type. Respondents were asked to estimate to what extent are the following factors important for the stability and development of your business: political (tax policy and political stability), economic (general economic growth and inflation rate), social (demographic structure of the population as well as cultural attitudes and values), technological (technological advancement/engineering, machines/ and informational technologies' /IT/ development), environmental (climate change and ecological aspect of environment), and legal (consumer and labor law). Hence, there were 12 factors (indicators) in total, grouped into six dimensions of the PESTEL model. In this study, "PESTLE data colletion and analysis methodology has been used. "PESTLE" analysis is conspicious with its traits similar to "SWOT" analysis. Typed as "PEST" or "PESTLE" substituting "Political", Economic, social, Technological, Legal, environmental analysis and in Turkish as 'politik, sosyal ve teknolojik analiz' by examining the organisation and its environment and accessing the important and vital ones which should be operated immediately and determining the positive and negative infuluences of these factors. The first study on this field is seen in anarticle written on "ETPS" standing for Economic, Technological Political and Socio-Culturel terms' first letters by Franchis J. Aguliar (1967). PEST analysis is usually an instrument to determine the events happening in the organisation but can be influenced by the improvements outsidei and at what stage that organisation is in terms of progress and towards which direction it is going. Reliability coefficient of the scale is measured as 0,87 . 
Each indicator could be estimated as having little importance (1), below average importance (2), average/moderate importance (3), significant importance (4), and very significant importance (5).

This instrument was derived by the author of this study directly from the PESTEL model, by choosing pairs of indicators for each dimension (factor). The author entitled it A short measure of PESTEL factors importance (SM-PFI). The reliability (to be more specific, the internal consistency) of SM-PFI was examined by calculating Cronbach's alpha coefficient (a). Some of the obtained coefficients were low; however, this was due to the small number of items for each PESTEL factor: $a=.725$ (social factors), $a=.711$ (legal factors, $a=.604$ (economic factors), $a=.613$ (technological factors), $a=.646$ (political factors), and $a=.702$ (environmental factors). The reliability check was supplemented by the results of correlational analysis. We calculated correlations within each pair of indicators for every PESTEL factor: social $(r=.287, p<.001)$, legal $(r=$ $.402, p<.001)$, economic $(r=.445, p<.001)$, technological $(r=.452, p<.001)$, political $(r=.481, p<.001)$, and environmental factors $(r=.552, p<.001)$. Obviously, all of the correlation coefficients were positive and statistically significant at the .001 level.

\subsection{Procedure}

Data were collected during the first half of February 2018. The researcher followed the ethical rules of conduct in social sciences (asking for informed consent from the participants, ensuring their anonymity, and declaring that the gathered data will be used for the scientific purposes only). The whole procedure lasted 20 minutes.

After the data had been collected, the researcher created their database in SPSS for Win where the further analyses were conducted. These statistical analyses included the calculation of descriptive statistical values (minimum, maximum, arithmetic means, and standard deviations) as well as several inferential procedures (repeated measures analysis of variance /RM ANOVA/ and correlational analysis). Participants' estimates of PESTEL dimensions were expressed as the mean values of pairs of their indicators.

\section{FINDINGS}

Firstly, the results of the descriptive statistical analysis were displayed (Table $1 \&$ Table 2). Secondly, the findings emerged from RM ANOVA (Table 3) were shown. Lastly, we displayed the correlational matrix of PESTEL dimensions, age, working experience, and education (Table 4).

Table 1. Descriptive Statistical Values Of 12 PESTEL Indicators

\begin{tabular}{lllll}
\hline PESTEL indicators & Min & Max & M & SD \\
\hline Tax policy & 1 & 5 & 3.90 & 0.92 \\
Political stability & 2 & 5 & 3.82 & 0.82 \\
\hline General economic growth & 2 & 5 & 4.06 & 0.76 \\
Inflation rate & 1 & 5 & 3.60 & 0.96 \\
\hline Demographic structure of the population & 1 & 4 & 3.00 & 0.87 \\
Cultural attitudes and values & 1 & 5 & 3.04 & 0.96 \\
\hline Technological advancement & 2 & 5 & 3.68 & 0.71 \\
Informational technologies' development & 1 & 5 & 3.56 & 0.88 \\
\hline Climate change & 1 & 5 & 3.46 & 0.88 \\
Ecological aspect of environment & 2 & 5 & 3.64 & 0.72 \\
\hline Consumer law & 3 & 5 & 4.22 & 0.54 \\
Labor law & 3 & 5 & 4.36 & 0.56 \\
\hline
\end{tabular}


As presented in Table 1, it seems that labor law (as one of the legal factors) is the most relevant influence to the tourism sector in Turkey because in this case, the average value of participants' estimates was the greatest one $(M=4.36)$. On the other hand, demographic structure of the population (as one of the social factors) had the weakest impact $(M=3.00)$ on the mentioned sector.

Table 2. Descriptive Statistical Values Of Six PESTEL Dimensions

\begin{tabular}{lllll}
\hline PESTEL dimensions & Min & Max & M & SD \\
\hline Political (P) & 1.50 & 5.00 & 3.86 & 0.75 \\
Economic (E) & 1.50 & 5.00 & 3.83 & 0.73 \\
Social (S) & 1.50 & 4.50 & 3.02 & 0.74 \\
Technological (T) & 1.50 & 5.00 & 3.62 & 0.68 \\
Environmental (E) & 1.50 & 5.00 & 3.55 & 0.70 \\
Legal (L) & 3.50 & 5.00 & 4.29 & 0.46 \\
\hline
\end{tabular}

Note. From now on, the second "E" was italicized so the distinction between economic and environmental factors could be highlighted. Taking into account the figures shown in Table 2, it seems that legal factors play a crucial role in Muğla city's tourism sector $(M=4.29)$. In contrast, social factors (according to managers' opinions) play only a minor role $(M=3.02)$ within this sector.

The statistical significance of differences between the importance of these six PESTEL dimensions (factors) was tested by carrying out repeated measures ANOVA (RM ANOVA), as shown in Table 3.

Wilks' Lambda statistic (.182) was statistically significant $(F=130.319, p<.001)$ which meant there was at least one statistically significant difference in importance of the six PESTEL dimensions. The effect size was $\eta^{2}=.818$ which indicated large differences between factors' importance for Turkish tourism sector. After all the groups and sub-group' being checked whether they all have been distributed singly, Rm Anova test was rewiewed.

Table 3. The Results Of RM ANOVA (Comparisons Between The Importance Of Six PESTEL Dimensions)

\begin{tabular}{|c|c|c|c|c|}
\hline Wilks' Lambda & $\mathbf{F}$ & $\eta^{2}$ & Differences & $\mathbf{M}_{\text {diff }}$ \\
\hline \multirow{15}{*}{.182} & \multirow{15}{*}{$130.319 *$} & \multirow{15}{*}{.818} & $\mathrm{P}-\mathrm{E}$ & .030 \\
\hline & & & $\mathrm{P}-\mathrm{S}$ & $.840 *$ \\
\hline & & & $\mathrm{P}-\mathrm{T}$ & $.240 *$ \\
\hline & & & $\mathrm{P}-E$ & $.310^{*}$ \\
\hline & & & $\mathrm{P}-\mathrm{L}$ & $-.430 *$ \\
\hline & & & $E-S$ & $.810^{*}$ \\
\hline & & & $\mathrm{E}-\mathrm{T}$ & $.210 *$ \\
\hline & & & $\mathrm{E}-E$ & $.280 *$ \\
\hline & & & $E-L$ & $-.460 *$ \\
\hline & & & $\mathrm{S}-\mathrm{T}$ & $-.600 *$ \\
\hline & & & $\mathrm{S}-E$ & $-.530^{*}$ \\
\hline & & & $\mathrm{S}-\mathrm{L}$ & $-1.270^{*}$ \\
\hline & & & $\mathrm{T}-E$ & .070 \\
\hline & & & $\mathrm{T}-\mathrm{L}$ & $-.670^{*}$ \\
\hline & & & $E-\mathrm{L}$ & $-.740 *$ \\
\hline
\end{tabular}

$* p<.001$ 
When we analyzed the significance of differences between each pair of PESTEL dimensions, the figures revealed the statistically significant importance of political and economic factors over social, technical, and environmental factors $(p<.001$ was obtained for all these differences). In the same time, political and economic factors were of the similar importance (because the difference between them was not statistically significant). Technological and environmental factors were significantly more important compared to social factors $(\mathrm{p}<.001)$. When we compared them with each other, there was no statistically significant difference. Hence, their level of importance was similar. Finally, legal factors were the most important group of factors within the PESTEL model/analysis. This is because participants estimated the impact of legal factors on the tourism sector in Muğla as significantly greater than the impact of the other five factors.

From Table 4, we can notice that participants' age was in weak positive and statistically significant correlations with the importance given to political $(r=.221, p<$ $.01)$, economic $(r=.187, p<.05)$, and environmental factors $(r=.196, p<.05)$. Therefore, older participants (compared to younger participants) gave greater estimates of importance with regard to political, economic, and environmental factors.

Table 4. Correlations Between Age, Years Of Working, Education, And PESTEL

\begin{tabular}{lllllll}
\hline & $\mathbf{P}$ & $\mathbf{E}$ & $\mathbf{S}$ & $\mathbf{T}$ & $\boldsymbol{E}$ & $\mathbf{L}$ \\
\hline Age & $.221^{* *}$ & $.187^{*}$ & -.088 & .064 & $.196^{*}$ & .092 \\
\hline Working years (present company) & .107 & .016 & $-.204^{*}$ & .130 & .067 & -.089 \\
\hline Working years (overall) & $.190^{*}$ & $.165^{*}$ & $-.172^{*}$ & .063 & .151 & .054 \\
\hline Education & $.412^{* * *}$ & $.358^{* * *}$ & $.479^{* * *}$ & $.304^{* * *}$ & $.526^{* * *}$ & $.317^{* * *}$
\end{tabular}

$* p<.05 ; * * p<.01 ; * * * p<.001$

Next, working years in the present company were in a weak, negative, and statistically significant correlation with the importance given to social factors $(r=-.204$, $p<.05)$. Hence, the longer managers worked in the present company, the less importance they gave to social factors. Overall working years were in weak positive and statistically significant relationships with the importance of political $(r=.190, p<.05)$ and economic factors $(r=.165, p<.05)$, and a weak negative and statistically significant correlation with the importance of social factors $(r=-.172, p<.05)$.

Finally, participants' levels of education were in moderate positive and statistically significant correlations with all the PESTEL factors $(p<.001)$. The lowest one was obtained for technological factors $(r=.304)$, whereas the highest correlation was calculated for environmental factors $(r=.526)$.

\section{DISCUSSION and CONCLUSION}

As was noted before, all PESTEL factors had at least moderate importance for the tourism industry in Muğla, Turkey. Further analysis yielded the following results. According to managers, legal influences were of the capital importance for this type of industry in Muğla, Turkey. Next, political factors had importance similar to that of economic factors. These two categories of influences were more important compared to technological, environmental, and social macroeconomic influences. According to 
managers' estimates, environmental factors were as important as technical factors and both groups of these influences were more important compared to social factors.

Indeed, political and legal factors, stemming from federal, local, state, and foreign governments, can represent chief opportunities or threats for large and small businesses (David 2011). Employers, stakeholders and other high-ranked business personnel overestimate the importance of legislation, politics, and economy while underestimating the effects of social factors. These factors include attitudes and beliefs, education, demographics, ethics, religion, lifestyles, social mobility, demographics, historical issues, and cross-cultural communication (Team FME 2013). As can be presumed, lots of them have a really great impact on, for example, customers' habits and competitors' value system. Thus, these factors should not be neglected by managers and other profiles in an organization or industry.

The importance attributed to political, economic, and environmental factors increases as participants' get older. On the other hand, the greater working experience, the less perceived importance of social factors. In contrast, the overall working experience was in positive correlation with the perceived importance of political and economic influences. An interesting finding included the positive correlation between managers' levels of education and the importance they attribute to all six PESTEL factors. As educational level increases, the impact of political, economic, social, technological, environmental and legal factors is estimated as more significant. Moreover, better-educated managers pay greater attention to social and environmental factors. These influences should be scanned firstly, then monitored and forecasted (i.e. by making feasible future projections), and finally, managers should assess their effects (Hitt, Ireland, \& Hoskisson 2007).

The present study had several practical implications. One of them was that legal, political, and economic factors of the macroeconomic environment should be taken seriously and monitored on a regular basis. Next was the importance of education in strategic management. Managers who are educated enough will pay attention to all the six factors of the PESTEL analysis and will not overlook their true impact. While making relevant business decisions, they will not diminish the significance of all of these environmental and external factors.

Of course, there were some limitations of this study. The first encompassed number of indicators of the PESTEL dimensions (factors). We chose a pair of indicator for each of these factors. Hence, we could ask ourselves: Were these pairs of indicators sufficient for capturing the true nature of each of the mentioned factors? The second shortcoming of the present study was the sample of participants. All of them were managers and probably this group of people had different perceptions of PESTEL factor relevance compared with other professionals in the tourism industry.

The PESTEL model of external environment analysis is applicable to the tourism sector of a country's industry. Other researchers should explore it with regard to local, national, and international (global) influences. Additionally, they can investigate the effects of an education in PESTEL analysis (that can be organized by one's company) on managers' estimates of the importance of those six factors.

Employers and owners of various organizations should invest in formal and nonformal educations of their employees so they can have a better, deeper, and broader picture of the external influences on the business they are part of. 
Finally, managers have to be well-skilled and competent in determining the influence of legal, political and economic challenges to their organization. However, they should keep in mind that social, technological, and environmental influences can sometimes be of a crucial importance as well. PESTEL analysis can be combined with SWOT analysis (which is about identifying strengths, weaknesses, opportunities, and threats to an organization) in order to make better and wiser strategic decisions and solutions.

\section{REFERENCES}

Andrei, Veronica \& Prisecaru, Ilie (2014). "The use of PESTEL analysis in development of the Romanian geological repository." U. P. B. Scientific Bulletin (Series C) 76: 247-254.

Barkauskas, Vytautas, Barkauskiene, Kristina, \& Jasinskas, Edumundas (2015). "Analysis of macro environmental factors influencing the development of rural tourism: Lithuanian case." Procedia: Social and Behavioral Sciences 213: 167172.

Cadle, James, Paul, Debra, \& Turner, Paul (2010). Business analysis techniques: 72 essential tools for success. Swindon, UK: BISL.

David, Fred (2011). Strategic management: Concepts and cases. New York: Prentice Hall.

Gillespie, Andrew (2016). Foundations of Economics (4th ed.). Oxford: Oxford Press.

Gregorić, Marina (2014). "PESTEL analysis of tourism destinations in the perspective of business tourism (MICE)." In Tourism and hospitality industry 2014 (Congress proceedings) (pp. 551-565). Retrieved from https:/www.fthm.uniri.hr/files/ Kongresi/THI /Papers/ 2014/THI_May2014_551to565.pdf

Gupta, Abhishek (2013). "Environment \& PEST analysis: An approach to external business environment." International Journal of Modern Social Sciences 2: 3443.

Hitt, Michael, Ireland, Duane, \& Hoskisson, Robert (2007). Strategic management: Competitiveness and globalization (Concepts and cases). Mason, $\mathrm{OH}$ : Thomson.

Ho, Joseph (2014). "Formulation of a systemic PEST analysis for strategic analysis." European Academic Research 2: 6478-6492.

Islam, Mohammad \& Pattack, Dulal (2017). "Impact of macro environmental factors on garments industry that drives export in Bangladesh." Studies in Business and Economics 12: 100-111.

Johnson, Gerry et al. (2011). Exploring strategy: Text \& cases. Harlow: Financial Times Prentice Hall.

Kolinos, Athanasios \& Read, George (2013). "A political, economic, social, technology, legal, and environmental (PESTLE) approach for risk identification of the tidal industry in the United Kingdom." Energies 6: 5023-5045. 
Mayaka, Melphon \& Prasad, Haushila (2012). "Tourism in Kenya: An analysis of strategic issues and challenges." Tourism Management Perspectives 1: 48-56.

Putra, Nengah et al. (2017). "The effect of strategic einvironment change toward Indonesia maritime security: Threat and opportunity." International Journal of Applied Engineering Research 12: 6037-6044.

Rauf, Abdul (2014). "Environmental strategic factor analysis of the tourism industry in the South coastal part of Sri Lanka." Journal of Emerging Trends in Economics and Management Sciences 5: 426-434.

Ritson, Neil (2008). Strategic management. Retrieved from http://ib.mdp.ac.id/ebook/ Karya\%20Umum/Karya\%20Umum-Neil\%20Ritson.pdf

Sammut-Bonnici, Tanya \& Galea, David (2015). "PEST analysis." In Wiley Encyclopedia of management (Volume 12. Strategic management). Retrieved from http://online library.wiley.com/doi /10.1002/9781118785317.weom120113/abstract

Steiss, Alan Walter (2003). Strategic management for public and nonprofit organizations. New York: Marcel Dekker, Inc.

Song, Jinbo, Sun, Yan, \& Jin, Lulu (2017). "PESTEL analysis of the development of the waste-to-energy incineration industry in China." Renewable and Sustainable Energy Reviews 80: 276-289.

Suri, Monika \& Kumar, Narendra (2016). "Tourism and hospitality industry sustainability in competition in India." Amity Research Journal of Tourism, Aviation, and Hospitality 1: 15-26.

Team FME (2013). PESTLE analysis: Strategy skills. Retrieved from http://www.freemanagement-ebooks.com/dldebk-pdf/fme-pestle -analysis.pdf

Ural, A. ve Kılıç, İ. (2006). Bilimsel araştırma süreci ve SPSS ile veri analizi. Ankara:

Detay Yayıncilık

Yüksel, Ihsan (2012). "Developing a multi-criteria decision making model for PESTEL analysis." International Journal of Business and Management 7: 52-66. 